\title{
Diseases in swine transmitted by artificial insemination: An overview
}

\author{
D. Maes ${ }^{\mathrm{a}, *}$, H. Nauwynck ${ }^{\mathrm{b}}$, T. Rijsselaere ${ }^{\mathrm{a}}, \mathrm{B}$. Mateusen ${ }^{\mathrm{a}}$, \\ P. Vyt ${ }^{a}$, A. de Kruif ${ }^{a}$, A. Van Soom ${ }^{a}$ \\ ${ }^{a}$ Department of Reproduction, Obstetrics and Herd Health, Faculty of Veterinary Medicine, Ghent University, \\ Salisburylaan 133, 9820 Merelbeke, Belgium \\ ${ }^{\mathrm{b}}$ Laboratory of Virology, Faculty of Veterinary Medicine, Ghent University, Salisburylaan 133, 9820 Merelbeke, Belgium
}

\begin{abstract}
Artificial insemination (AI) of swine is widely practiced in countries with an intensive pig production. It is a very useful tool to introduce superior genes into sow herds, with minimal risk for disease transmission. However, the impact of semen that is contaminated with pathogens can be enormous. Most of the micro-organisms that have been detected in boar semen are considered non-pathogenic, but some are known pathogens (e.g. porcine reproductive and respiratory syndrome virus) that can cause major economic losses. Microbial contamination of semen can be due to systemic and/or urogenital tract infections of the boar, or can occur during collection, processing and storage. It can result in reduced semen quality, embryonic or fetal death, endometritis and systemic infection and/or disease in the recipient female. Conventional techniques for isolation of bacteria and viruses from the semen do not always provide optimal results for various reasons, including lack of sensitivity and speed of testing, and difficult interpretation of the outcome. More recently, PCR tests are commonly used; they have a high sensitivity, the outcome is quickly obtained, and they are suitable for monitoring a large number of samples. The best strategy to prevent AI-transmitted diseases is to use boars that are free of specific pathogens, to monitor the animals and semen regularly, and to maintain very high biosecurity. Additional measures should be directed at treating semen with appropriate antimicrobials, and at reducing contamination during semen collection, processing, and storage.
\end{abstract}

(C) 2008 Elsevier Inc. All rights reserved.

Keywords: Semen; Pig; Artificial insemination; Disease transmission; Review

\section{Introduction}

Artificial insemination (AI) of swine is widely practiced in countries with intensive pig production. In Western Europe, $>90 \%$ of the sows have been bred by AI for more than two decades [1]. When compared with natural mating, AI is a very useful tool to introduce

\footnotetext{
* Corresponding author. Tel.: +329264 75 42; fax: +329264 7534 .

E-mail address: Dominiek.Maes@UGent.be (D. Maes).
}

superior genes into sow herds, with a minimal risk of disease.

Sources of microbial contamination of the semen can be classified arbitrarily as being from animal or nonanimal origin. Contamination of animal origin can be due to general or local infections within the boar, and shedding through the testes and other tissues of the genital tract. It can also originate from preputial cavity fluids, respiratory secretions, and feces during collection and processing. Contamination of non-animal origin mostly originate from the person collecting the semen (hair, skin, respiratory secretions), from the 
water used during processing (e.g. water lines, holding tanks), the air/ventilation system, and from sinks/drains.

Semen that is contaminated with too many microbes or that contains specific pathogens may lead to major economic losses for the AI center and/or the sow herd. Adverse effects include (temporary) infertility and reduced sperm production of the boars, less fertile sperm with lower reproductive performance in the sow herds, endometritis, clinical disease in the sow herds, or infections with unwanted pathogens, leading to reduced health status, stamping out, or regulatory measures. Although the risk for disease transmission following AI may be minimal, the impact of semen that is contaminated with pathogens can be enormous, especially if a large number of sow herds is involved.

The present paper will review the most important pathogens found in porcine semen used for AI, the effects of infection with these pathogens on the recipient female, the diagnostic procedures that can be used, and various control measures that can be applied to limit or prevent contamination of semen used for AI.

\section{Pathogens present in boar semen}

\subsection{Bacteria}

Boar ejaculates usually contain $10^{4}$ to $10^{5}$ bacteria/ $\mathrm{mL}$ [2]. The majority of them are Gram-negative bacteria, with a large percentage originating from the family Enterobacteriaceae. A list of the bacteria found in freshly collected, undiluted boar ejaculates, is summarized by Althouse and $\mathrm{Lu}$ [3]. Most are nonpathogenic, but they can have spermicidal effects, especially if present in high concentrations [4]. Bacteria can also be present in extended semen, and they may negatively influence the quality and longevity of the semen. Many of these bacteria are resistant to the antimicrobials that are commonly used in commercial semen extenders [3].

Apart from these contaminating bacteria, boars can also become infected with specific bacterial pathogens that may be transmitted by the semen. Antimicrobials which are commonly present in commercial extenders (aminoglycosides, B-lactams and lincosamides) for AI may suppress these pathogens. However, complete elimination cannot be guaranteed, since the bacterial pathogen may not be susceptible to the antimicrobial because of innate or acquired antimicrobial resistance or environmental conditions (e.g. temperature) that hamper the optimal activity of the antimicrobial. Therefore, transmission of bacterial pathogens can occur by AI, even if antimicrobials are added to the extended semen.

\subsubsection{Brucellosis}

Swine brucellosis is widespread in South America, Africa, and Asia. In the European Union and North America, there is a low prevalence or the disease has been eradicated. It is a venereal disease; therefore, sows are readily infected when mated with infected boars [5]. The classic manifestations of pig brucellosis are abortion, infertility, orchitis, posterior paralysis, and lameness. Abortions have been observed as early as $17 \mathrm{~d}$ following natural breeding by boars disseminating $B$. suis in the semen. Infertility due to testicular involvement and lack of sexual drive may occur in infected boars. More commonly, the accessory genital glands are infected. In these cases, boars remain fertile and may disseminate large numbers of $B$. suis in their semen for a prolonged interval [6]. Boars infected with B. suis biovar 1, 2 or 3 generally do not have clinically apparent lesions.

\subsubsection{Chlamydia sp.}

Porcine chlamydiosis has been associated with a wide range of diseases, including reproductive disorders. Most infections however are subclinical. Chlamydiae can cause inflammation of the boar's urogenital tract, and have been detected in semen of boars. Using PCR testing in boars of two studs, Kauffold et al. [7] found Chlamydophila psittaci and Chlamydia suis as the most frequent types, with the former predominating in semen (in 23 out of 33 positive samples) and the latter in feces (68/73). These findings suggest a potential for venereal transmission.

\subsubsection{Leptospirosis}

Leptospirosis has been reported in swine from all parts of the world. The disease mainly causes reproductive problems in breeding herds (abortion, stillborn piglets and infertility). Clinical symptoms and infertility may also occur in acutely infected boars. Venereal transmission is thought to play an important role in the spread of infections with serovar bratislava. Leptospires may persist for extende intervals in kidneys and genital tracts of sows and boars, and be excreted in urine and genital tract fluids [8].

\subsubsection{Mycoplasma sp.}

Infection of the genitourinary tract with mycoplasmas is common in many animal species, however little evidence has been presented reporting similar findings in swine. Transmission of Mycoplasma suis by semen is 
rare, since it only occurs in the case of blood contamination [9]. Shin et al. [10] demonstrated a pathogenic strain of $M$. hyorhinis thought to cause abortions in sows. However, the clinical relevance of Mycoplasma sp. in relation to reproductive performance remains doubtful.

\subsubsection{Tuberculosis}

Infections with Mycobacterium avium are most common in swine, but infections with Mycobacterium tuberculosis and Mycobacterium bovis also occur. Mycobacterium sp. can enter the semen if the infection has localized in the reproductive tract.

\subsection{Viruses}

Many viruses have been recovered from the semen of infected boars (Table 1), or have been reported in relation to infertility or reduced reproductive performance in swine [11]. In general, the risk of virus to be present in semen is highest during clinical disease. However, under practical circumstances, sperm collection will not take place from clinically affected boars and consequently the risk of pathogen transmission to the sow is low. It is noteworthy that virus shedding can start prior to the development of clinical signs, clinical signs can be mild or absent, or acutely infected boars can remain unnoticed by their caretakers. Furthermore, viral shedding may continue long after clinical signs have abated. In these situations, the risk of virus transmission is much higher, as no special control measures will be taken.

\subsubsection{African swine fever virus}

African swine fever virus replicates first in the monocytes and macrophages of the lymph nodes near the place that the virus entered, and it subsequently spreads through the blood and/or lymphatic system in the body. It has been suggested that the virus can also be found in the semen after infection in boars, and even be transmitted to recipient sows [12]. However, there is no published evidence to support this hypothesis. No treatment or effective vaccines are available.

\subsubsection{Classical swine fever (CSF) virus and other pestiviruses}

Although the CSF virus is eradicated in many countries, it has been periodically reintroduced into domestic pigs via contact with wild boars. Boars experimentally infected with CSF virus shed the virus in semen for up to $53 \mathrm{~d}$ post-infection [13]. Sows that were inseminated with contaminated semen seroconverted, had embryonic mortality, and virus was isolated from the fetuses [14]. During the CSF epidemic in The Netherlands in 1999, two AI centers became infected and 1680 pig herds were declared CSF-suspect [15]. This disease will remain important because the virus is very contagious and it is not always associated with prominent clinical and pathological signs, especially in breeding pigs.

Pigs are also susceptible to other pestiviruses, including bovine viral diarrhea virus (BVDV) and border disease virus (BDV). Congenitally infected pigs may shed large amounts of virus. Terpstra and Wenswoort [16] isolated BVDV from oropharyngeal fluid, urine and semen of a congenitally infected, infertile boar.

\subsubsection{Foot and mouth disease (FMD) virus and swine vesicular disease (SVD) virus}

The FMD and SVD viruses have been recovered from semen from infected boars for up to 9 and $4 \mathrm{~d}$ postinfection, respectively, but AI with contaminated semen failed to transmit the disease to sows [17]. Infection with FMD virus leads to viremia, with subsequent dissemination of the virus throughout virtually all tissues of the body, including the genital tract and the skin around the preputial orifice [18]. The viral concentration in semen has been found to be low. Since infections with both viruses are officially eradicated in many countries, and since boars are intensively monitored in other countries, the risk for transmission of these viruses by the semen is low.

\subsubsection{Japanese encephalitis virus}

Japanese encephalitis virus is a mosquito-borne pathogen affecting humans and animals. The virus is an economically important reproductive pathogen of breeding pigs, especially in Asia and Northern Australia. Infection of susceptible boars resulted in edematous, congested testes that produced semen with numerous abnormal spermatozoa and significantly decreased total and motile sperm counts [19]. These changes are usually temporary and most boars recover completely. Virus can be shed in the semen for 5 weeks.

\subsubsection{Porcine circovirus type 2 (PCV2)}

The PCV2 has been identified as being associated with the Post Weaning Multi-systemic Wasting Syndrome (PMWS). The virus has also been linked to a number of other disease conditions, including reproductive failure (late term abortions and stillbirths). 
Table 1

Important pathogenic swine viruses that have been found in semen from infected boars ${ }^{\mathrm{a}}$

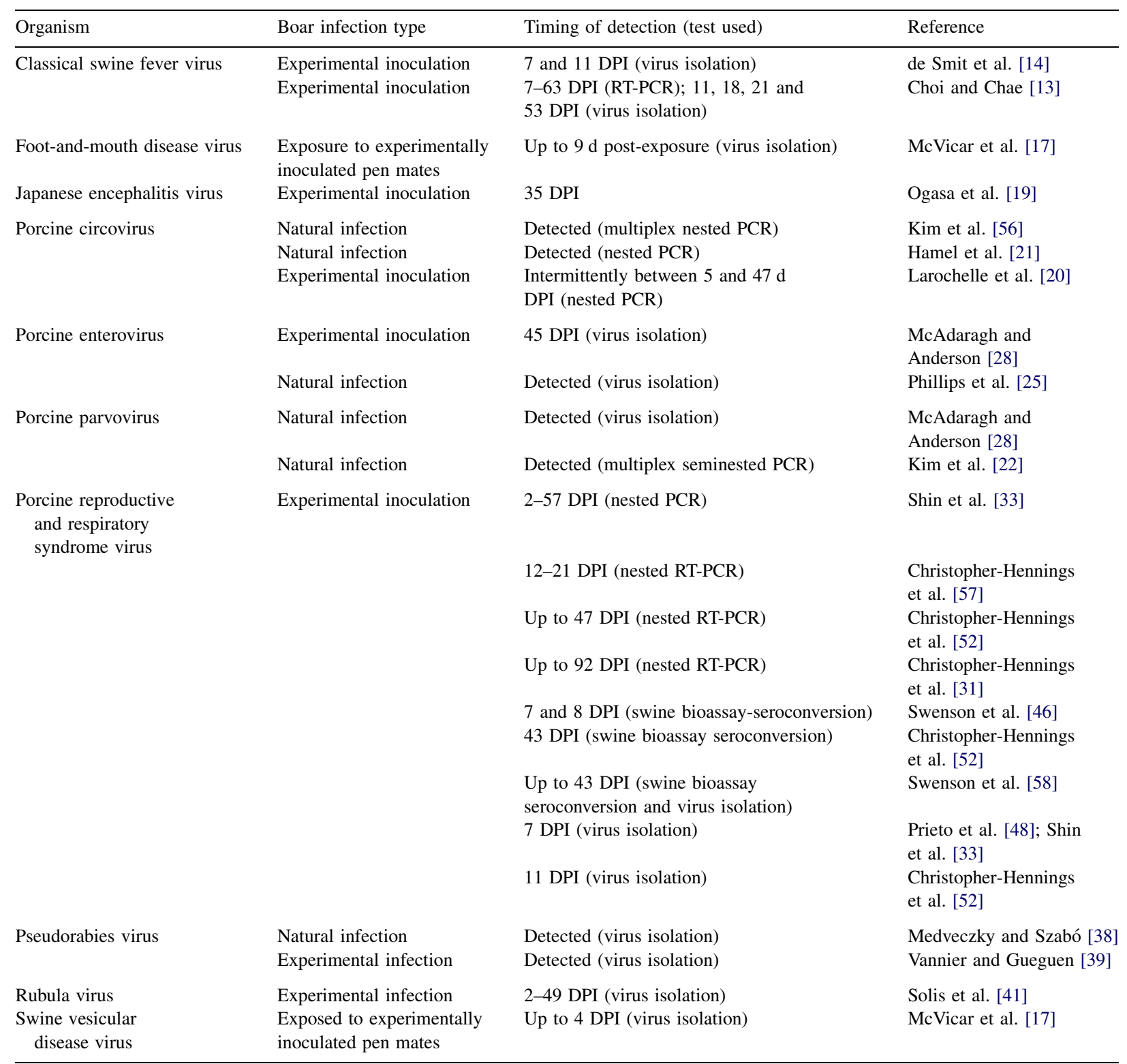

DPI = days post-inoculation; PCR = polymerase chain reaction; RT-PCR = reverse transcriptase-polymerase chain reaction.

${ }^{a}$ Adapted from Amass and Baysinger [55].

However, PCV2-associated reproductive disease under field conditions is rare. This virus has been detected in semen of naturally and experimentally infected boars, even after the appearance of antibodies in the serum [20]. Shedding in the semen was detected between 5 and $47 \mathrm{~d}$ after infection. The seminal plasma is usually contaminated, but PCV2 is also frequently detected in the sperm and non-sperm cell fractions [21,22]. That this virus can be intermittently excreted by infected boars, semen may be an important means of transmission. The virus is also able to replicate in zona pellucida-free embryos, leading to embryonic death $[23,24]$.

\subsubsection{Porcine enteroviruses}

Porcine enteroviruses may cause reproductive failure in sows (fetal death and mummification, stillbirth, and weak born piglets). They are highly resistant in the 
environment and may survive for prolonged intervals in feces. Porcine enteroviruses have also been isolated from the male genital tract [25], although the insemination of gilts with contaminated semen did not influence fertility [26]. Contamination of semen during collection of semen is possible. Infections in boars may lead to seminal vesiculitis, sperm abnormalities, and decreased libido.

\subsubsection{Porcine parvovirus (PPV)}

The PPV can induce embryonic death, mummification, and stillbirth in non-immune pregnant sows. Usually, no clinical signs following infection are observed in boars. Biront and Bonte [27] did not find evidence for altered fertility or libido of boars following infection with PPV. Boars can shed the virus in semen during the acute phase of infection [28]; shedding beyond this phase has not been demonstrated, but the possibility of immunotolerant carriers of PPV as a result of early in utero infection has been suggested [29]. Semen may also become contaminated by feces containing virus, or within the male reproductive organs $[27,30]$.

\subsubsection{Porcine reproductive and respiratory syndrome virus (PRRSV)}

Clinical signs following PRRSV infection vary widely, ranging from reproductive failure in breeding animals, mortality in suckling pigs, to respiratory disease in nursery and grow-finishing pigs. Infected animals can shed PRRSV in saliva, nasal secretions, urine, feces, and also in semen. The virus can be shed in semen, even in the absence of viremia and in the presence of neutralizing antibodies [31,32]. This virus most likely reaches the tissues of the reproductive tract and semen by migration of infected monocytes and macrophages [49]. The duration of shedding in semen samples of experimentally infected boars varies widely, ranging from $2 \mathrm{~d}$ [33] to $92 \mathrm{~d}$ [31] after infection (Table 1 ). This marked variability may be due to various factors, including individual boar variation, possibly the type of virus strain, and the technique used for detection of the virus (i.e. virus isolation, PCR, RT-nPCR, swine bioassay). Semen shedding has also been demonstrated after vaccination with a modified live vaccine virus [34]. Alterations in seminal quality following PRRSV infection have an individual character, and include reduced motility, an increase in the percentage of abnormal acrosomes, and an increase in morphologically abnormal sperm, especially those with abnormal heads [35].

\subsubsection{Porcine retroviruses}

Pigs carry porcine endogenous retroviruses (PERVs), but they are not known to cause disease in pigs. Infection cannot be prevented within a pig, since it is embedded in the genome. Recent reports however indicate that the human-tropic form of PERV may, in some pig breeds, be an exogenous infection [36], and that the pig germline may not contain a replicationcompetent human-tropic PERV. Perhaps a selective breeding program of pigs that do not contain humantropic PERV sequences in the germline would allow development of a herd that are less likely to express the human-tropic PERV. Further research regarding the transmission of these viruses is necessary.

\subsubsection{Pseudorabies virus (PRV) (Aujeszky's disease virus) and suid herpesvirus 2}

The PRV is a herpes virus that is primarily transmitted by nose-to-nose contact, with viral replication in the nasal and pharyngeal mucosa. Viral replication also occurs in the genital tract. After experimental infection by the intratesticular route, testicular degeneration and transient elevation in sperm abnormalities have been reported [37]. The virus can be irregularly isolated from urine, preputial membranes, or semen, after either natural [38] or experimental infection [39]. Very high viral concentrations (from $10^{3.7}$ to $10^{9} \mathrm{TCID}_{50} / \mathrm{mL}$ ) have been reported in semen. Virus excretion is not strictly associated with clinical disease, or with a reduction in semen quality, and recrudescence of boars latently infected with PRV constitutes a permanent risk. Clinically infected boars are often unable to mount. Sows inseminated with contaminated semen show seroconversion, and may suffer from vaginitis, endometritis, and embryonic mortality. In many countries, vaccination is done as part of an eradication program.

Infection with porcine cytomegalovirus or suid herpesvirus 2 is usually subclinical in adults. Following infection in boars, the virus could be detected in the testis and the epididymis [40]. However, shedding of virus in ejaculated semen has not been determined.

\subsubsection{Rubula virus (Blue eye disease)}

Blue eye disease, due to infection with blue eye paramyxovirus or porcine rubula virus, is an important pathogen in Mexico and causes reproductive problems in breeding pigs. Boars, like other adult animals, generally do not show clinical signs, except for epididymo-orchitis and in severe cases, loss of libido. Transmission of the virus through semen to the sow has not been proven experimentally, but virus could be 
recovered from semen, testis, and other tissues of the reproductive tract for up to $49 \mathrm{~d}$ after inoculation [41]. Based on semen evaluation, in herds infected with rubula virus, approximately $30 \%$ of boars have temporary or permanent infertility. Semen abnormalities include a decrease in concentration, increased morphologically abnormal sperm, decreased sperm motility and viability, and azoospermia (in some boars).

\section{Effects of microbial contamination on the recipient sow}

Microbial contamination of semen can result in reduced conception rates due to reduced semen quality, early embryonic death and/or endometritis, clinical disease in the sow herds, and/or infections with unwanted pathogens, leading to reduced health status, stamping out, or regulatory measures.

Early embryonic death may result from direct invasion of the embryo by the pathogen, and/or by induced uterine epithelial changes (e.g. with PPV) [42]. The zona pellucida, surrounding the developing embryo until 6-7 d after conception, forms an impervious barrier to penetration by many pathogens, including PPV, PRV, PCV2, and PRRSV [43]. However, after hatching, blastocyst-stage embryos may become susceptible to the infection, as is in the case of PRV. Endometritis with failure to conceive or early embryonic death may develop if the semen dose is too heavily contaminated with bacteria, and/or if timing of $\mathrm{AI}$ is not appropriate.

Transmission of the pathogen by semen to the sow has been clearly proven for CSF [14] and PRRS virus [44] after experimental inoculation of boars, and for porcine parvovirus [30] and PRRS virus [45,46] after experimental inoculation of semen. Therefore, although contaminated semen does indeed constitute a serious risk for transmission, it does not guarantee that transmission of these pathogens to the sow by AI will consistently occur (e.g. PRRSV) $[44,46]$. The conditions required for establishment of infection in the sow are complex, and lack of transmission might be explained by other factors, e.g. sow immunity or failure to reach the minimum infectious dose. Recently, much research has been conducted concerning the risk of transmission of PRRSV by semen and the minimum dose necessary to establish infection in the sow. Pigs are much more susceptible to PRRSV infection via parenteral exposure than via other routes (oral, intranasal, via AI). Exposure to 20 or fewer PRRSV particles by intramuscular exposure resulted in infection, whereas the infectious dose ${ }_{50}\left(\mathrm{ID}_{50}\right.$, i.e. the dose required to infect one-half of the exposed animals) for exposure via oral and intranasal routes and via $\mathrm{AI}$ were $10^{5.3}, 10^{4.0}$ and approximately $10^{4.5}$, respectively [47]. Prieto et al. [48] reported the PRRSV titer in an ejaculate of an infected boar to be $7 \times 10^{2} \mathrm{TCID}_{50} / \mathrm{mL}$ of fresh semen. If the ejaculate is extended (15-30 times), the virus titer will be approximately $4 \times 10^{1} \mathrm{TCID}_{50} / \mathrm{mL}$ of extended semen, corresponding with a total amount of $4 \times 10^{3}$ TCID $_{50}$ of PRRSV in each dose $(100 \mathrm{~mL})$ of extended semen.

Apart from the total amount of infectious particles present in the semen, statistical aspects, in particular the number of sows inseminated with a particular lot of contaminated semen, determine the likelihood of venereal transmission. For example, if it requires $10^{5}$ TCID $_{50}$ of PRRSV to consistently result in venereal transmission [47], on average a single female would become infected if $10^{5}$ females were each inseminated with semen contaminated with 1 TCID $_{50}$ of PRRSV. This may account for the difficulty in maintaining very large herds free of PRRSV [49].

\section{Diagnostics and monitoring}

Microbiologic analysis of semen is difficult. Bacteria are numerous, resulting in contamination of cell culture systems for virus isolation and overgrowth of special media for growing fastidious organisms. Interpretation of pathogenic versus non-pathogenic bacterial isolates is confusing. Virus isolation is further complicated by the existence of cytotoxic factors in semen that destroy cell culture systems and antiviral factors that nonspecifically neutralize virus [50]. Swine bioassays have been used for detecting viruses, and they may be more sensitive than cell culture systems. However, animal inoculations cannot be justified to be used systematically from an animal welfare perspective and they are not suitable for testing large numbers of samples in a short interval. As diluted boar semen is mostly used within $3 \mathrm{~d}$ after collection, the outcome of analysis should be available within a very short time.

Recently, much progress has been made concerning the quality of diagnostic tests, in terms of speed of testing and increased sensitivity. In that regard, PCR techniques have become available for testing different pathogens that may be present in boar semen [51]. However, as PCR testing detects only a portion of the genome rather than the infectious organism, a positive result by PCR does not necessarily mean that the sample contains infectious pathogens. In the case of PRRSV, RT-nPCR is generally considered to be the most sensitive diagnostic technique. It allows for the 
detection of as little as $100 \mathrm{TCID}_{50} /$ seminal dose [52], 20 times less virus than that shown experimentally to result in venereal transmission of PRRV in one of five gilts [47].

For interpretation of diagnostic results of semen samples at group level, in addition to the detection limit of the diagnostic method used, it is also important, to test a representative number of semen samples and to include also testing of other parameters, e.g. presence of serum antibodies, viremia or bacteremia, clinical symptoms, etc. In the case of PRRSV, however, any attempt to categorize semen as either virus-free or viruscontaminated is complicated by temporal inconsistencies among viremia, the presence of PRRSV in semen, and serostatus [49]. For example, viremia in adult boars is of short duration and usually ends before cessation of virus shedding in semen. Conversely, in the initial phases of the infection, serological results will be positive, even though virus is not being shed in the semen [59]. Finally, boars are likely to remain serologically positive long after PRRSV is no longer shed in the semen. Since shedding of the virus in semen, especially in the chronic phase of the infection, is intermittent, it is possible to get a negative result by RTnPCR testing of a semen sample, even though the boar is still capable of subsequently shedding PRRSV in semen. Therefore, a negative result only means that the tested sample does not contain virus, and that the particular ejaculate is likely to be virus-free. It does not provide certainty that there will be no risk of contamination in the future. Consequently, a negative semen test from a serologically positive boar should be interpreted with caution. Also for other pathogens that can be shed in semen, similar considerations should be made regarding possible inconsistencies in outcomes of various tests and samples.

\section{Preventive measures}

To prevent possible spread of infectious diseases via AI, several precautionary measures should be undertaken in AI centers. First, individual hygiene and general sanitation procedures are important. Personnel collecting semen or coming into contact with any materials, need to understand that they can be a source of contamination or act as a carrier in transferring contamination. To minimize the bacterial load originating from the boar, the ventral abdomen should be clean and dry. Preputial fluids, which can contain high numbers of microbes, should be evacuated prior to exteriorization of the penis for semen collection. A detailed list of measures that can be taken to minimize the risk of contamination are reported by Althouse et al. [4]. To reduce the unavoidable presence of bacteria in the ejaculate and to prolong in vitro longevity of sperm, preservative levels of antimicrobials are an essential constituent of any semen extender. Apart from a possible dilution effect of pathogens, semen processing and addition of antimicrobials however do not eliminate viruses. The use of effective antiviral agents to render semen virus-free has so far not been adopted in the swine AI industry. Monitoring for bacterial contamination of the extended semen samples may constitute an important part of a control program. Harmless organisms that have no negative influence on sperm quality and sow herds do not need to be monitored, except if they exceed a certain threshold or would have an indicator function.

Housing and management practices should be appropriate for keeping animals in optimal health and for optimizing sperm output. The health status of the animals should be checked daily. However, as indicated before, clinical examination alone is insufficient, since clinically normal boars can shed pathogens (e.g. CSF virus, FMD virus, PRV, and $B$. suis) in their semen. Vaccination of the boars can be considered for some pathogens; for example, vaccination against parvovirus may help to reduce shedding of the virus following infection. In the case of PRRSV, the use of a modified live virus vaccine shortened or eliminated virus shedding in boars challenged with wild-type virus $50 \mathrm{~d}$ after vaccination [34]. In contrast, an inactivated vaccine did not clearly reduce subsequent shedding of wild-type virus in semen [53,54]. However, vaccine virus of a modified live PRRSV vaccine can be shed in the semen [34]. According to European Union legislation, modified live vaccines against Aujeszky's disease may not shed vaccine virus in the semen. As far as PCV2 is concerned, the present scientific data are insufficient to develop reliable measures to manage PCV2 infections in commercial AI centers.

Given the possible disastrous consequences of contaminate semen, adhering to very strict biosecurity measures is a conditio sine qua non for AI centers. The best way to prevent transmission of diseases by $\mathrm{AI}$ is to use boars that are free of the pathogen, and to maintain very strict biosecurity measures to prevent intake and/or spread of these pathogens in the AI center. Systems for filtering the incoming air in AI centers can be done to safeguard boars against the entry of airborne pathogens. Eradication programs rely heavily on monitoring a representative number of boars for specific pathogens or serum antibodies, and the rejection and/or elimination 
of any infected or reactive animal. Some diseases are subject to an official eradication program, including FMD, CSF, Aujeszky's disease, and Brucellosis. However, for some diseases, e.g. PRRSV and PCV2, no control program has been integrated into any international or European Union legislation, and control strategies for these diseases may vary between countries or even between AI centers. If SPF-status cannot be maintained for some pathogens, appropriate control measures (e.g. vaccination) can be taken, with very strict hygiene during semen collection, processing, and distribution.

\section{Conclusions}

Although the presence of a pathogen in semen used for AI is not proof of causing infection in the sow herd, there is always a risk. The risk increases with the number of pathogens in the semen, the number of sows inseminated with the contaminated semen, and in the absence of protective immunity in the sow population. Since the best way to prevent disease is the absence of the pathogen, AI centers should strive to use boars that are free of major pathogens. Animals should be quarantined and tested before introduction into $\mathrm{AI}$ centers, strict biosecurity measures should be maintained, and a statistically appropriate number of animals and samples should be tested periodically for a wide variety of organisms. In this way, commercial AI centers can assure that their products exclude specific pathogens and contain a minimal (acceptable) number of micro-organisms.

\section{References}

[1] Gerrits R, Lunney J, Johnson A, Pursel V, Kraeling R, Rohrer G, et al. Perspectives for artificial insemination and genomics to improve global swine populations. Theriogenology 2005;63:283-99.

[2] Sone M. Investigations on the control of bacteria in boar semen. Jpn J Anim Reprod 1990;36:23-9.

[3] Althouse G, Lu K. Bacteriospermia in extended porcine semen. Theriogenology 2005;63:573-84.

[4] Althouse G, Kuster C, Clark S, Weisiger R. Field investigations of bacterial contaminants and their effects on extended porcine semen. Theriogenology 2000;53:1167-76.

[5] Lord V, Cherwonogrodzky J, Marcano M, Melendez G. Serological and bacteriological study of swine brucellosis. J Clin Microbiol 1997;35:295-7.

[6] Vandeplassche M, Herman J, Spincemaille J, Bouters R, Dekeyser P, Brone E. Brucella suis infection and infertility in swine. Meded Veeartsenijsch Rijksuniv Gent 1967;11:1-40.

[7] Kauffold J, Melzer F, Henning K, Schulze K, Leiding C, Sachse $\mathrm{K}$. Prevalence of chlamydiae in boars and semen used for artificial insemination. Theriogenology 2006;65:1750-8.
[8] Ellis W, McParland P, Bryson D, Cassels J. Boars as carriers of leptospires of the Australis serogroup on farms with an abortion problem. Vet Rec 1986;118:563.

[9] Heinritzi K. Eperythrozoönosis. In: Straw B, D'Allaire S, Mengeling W, Taylor D, editors. Diseases of swine. 8th ed., Ames, IA, USA: Iowa State University Press; 1999. p. 413-8.

[10] Shin J, Joo HS, Lee W, Deok H, Calsamiglia M, Pijoan C, et al. Identification and characterization of cytopathogenic Mycoplasma hyorhinis from swine farms with a history of abortions J Vet Med Sci 2003;65:501-9.

[11] Guérin B, Pozzi N. Viruses in boar semen: detection and clinical as well as epidemiological consequences regarding disease transmission by artificial insemination. Theriogenology 2005; 63:556-72.

[12] Thacker B, Larsen R, Joo HS, Leman A. Swine diseases transmissible with artificial insemination. J Am Vet Med Assoc 1984;185:511-6.

[13] Choi C, Chae C. Detection of classical swine fever virus in boar semen by reverse transcription-polymerase chain reaction. J Vet Diagn Invest 2003;15:35-41.

[14] de Smit A, Bouma A, Terpstra C, van Oirschot J. Transmission of classical swine fever virus by artificial insemination. Vet Microbiol 1999;67:239-49.

[15] Hennecken M, Stegeman J, Elbers A, Van Nes A, Smak J, Verheijden J. Transmission of classical swine fever virus by artificial insemination during the 1997-1998 epidemic in The Netherlands: a descriptive epidemiological study. Vet Q 2000; 22:228-33.

[16] Terpstra C, Wenswoort G. A congenital persistent infection of bovine viral diarrhea virus in pigs: clinical, virological and immunological observations. Vet Q 1997;19:97-101.

[17] McVicar J, Eisner R, Johnson L, Pursel V. Foot-and-mouth disease and swine vesicular disease viruses in boar semen.. In: Proceedings of the 81 st annual meeting of the American animal health association; 1978. p. 221-30.

[18] Alexandersen S, Oleksiewicz M, Donaldson A. The early pathogenesis of foot-and-mouth disease in pigs infected by contact: a quantitative time-course study using TaqMan RT-PCR. J Gen Virol 2001;82:747-55.

[19] Ogasa A, Yokoki Y, Fujisaki Y, Habu A. Reproductive disorders in boars infected experimentally with Japanese encephalitis virus. Jpn J Anim Reprod 1977;27:21-6.

[20] Larochelle R, Bielanski A, Müller P, Magar R. PCR detection and evidence of shedding of porcine circovirus type 2 in boar semen. J Clin Microbiol 2000;38:4629-32.

[21] Hamel A, Lin L, Sachvie C, Grudeski E, Nayar G. PCR detection and characterization of type- 2 porcine circovirus. Can J Vet Res 2000;64:44-52.

[22] Kim J, Han D, Choi C, Chae C. Simultaneous detection and differentiation between porcine circovirus and porcine parvovirus in boar semen by multiplex seminested polymerase chain reaction. J Vet Med Sci 2003;65:741-4.

[23] Mateusen B, Sanchez R, Van Soom A, Meets P, Maes D, Nauwynck H. Susceptibility of pig embryos to porcine circovirus type 2 infection. Theriogenology 2004; 61:91-101.

[24] Mateusen B, Maes D, Van Soom A, Lefebvre D, Nauwynck H. Effect of a porcine circovirus type 2 infection on embryos during early pregnancy. Theriogenology 2007;68:896-901.

[25] Phillips R, Foley C, Lukert P. Isolation and characterization of viruses from semen and the reproductive tract of male swine. $\mathrm{J}$ Am Vet Med Assoc 1972;161:1306-16. 
[26] De Meurichy W, Pensaert M. Effect of an enterovirus in gilts inseminated with a semen-virus mixture. Zentralbl Veterinarmed B 1977;24:97-103.

[27] Biront P, Bonte P. Porcine parvovirus: infection in boars. I. Possibility of a genital localization in the boar after oronasal infection. Zentralbl Veterinarmed B 1983;30:541-5.

[28] McAdaragh J, Anderson G. Transmission of viruses through boar semen. In: Proceedings of the 18th annual meeting of the American association of veterinary laboratory diagnosticians; 1975. p. 69-76.

[29] Cartwright S, Lucas M, Huck R. A small haemagglutinating porcine DNA virus. II. Biological and serological studies. J Comp Pathol 1971;81:145-55.

[30] Lucas M, Cartright S, Wrathall A. Genital infection of pigs with porcine parvovirus. J Comp Pathol 1974;84:347-50.

[31] Christopher-Hennings J, Nelson E, Hines R, Nelson J, Swenson $\mathrm{S}$, Zimmerman J, et al. Persistence of porcine reproductive and respiratory syndrome virus in serum and semen of adult boars. $\mathbf{J}$ Vet Diagn Invest 1995;7:456-64.

[32] Christopher-Hennings J, Holler L, Benfield D, Nelson E. Detection and duration of porcine reproductive and respiratory syndrome virus in semen, serum, peripheral blood mononuclear cells, and tissues from Yorkshire, Hampshire and Landrace boars. J Vet Diagn Invest 2001;13:133-42.

[33] Shin J, Torrison J, Choi C, Gonzalez S, Crabo B, Molitor T. Monitoring of porcine reproductive and respiratory syndrome virus infection in boars. Vet Microbiol 1997;55:337-46.

[34] Christopher-Hennings J, Nelson E, Nelson J, Benfield D. Effects of a modified-live vaccine against porcine reproductive and respiratory syndrome virus in boars. Am J Vet Res 1997;58:40-5.

[35] Feitsma H, Grooten H, van Schie F, Colenbrander B. The effect of porcine epidemic abortion and respiratory syndrome (PEARS) on sperm production. In: Proceedings of the 12th international congress on animal reproduction; 1992. p. 1710-2.

[36] Wood J, Quinn G, Suling K, Oldmixon B, Van Tine B, Cina R, et al. Identification of exogenous forms of human-tropic porcine endogenous retrovirus in miniature swine. J Virol 2004;78: 2494-501.

[37] Hall L, Kluge J, Evans L, Clark T, Hill H. Testicular changes observed in boars following experimental inoculation with pseudorabies virus. Can J Comp Med 1984;48:303-7.

[38] Medveczky I, Szabó I. Isolation of Aujeszky's disease virus from boar semen. Acta Vet Acad Sci Hungaricae 1981;29:29-35.

[39] Vannier P, Gueguen B. Excrétion du virus de la maladie d'Aujeszky par les voies genitals mâles du porc. J Rech Porcine 1979;401-6.

[40] Shirai J, Narita M, Iijima Y. A cytomegalovirus isolation from swine testicle culture. Jpn J Vet Sci 1985;47:697-703.

[41] Solis M, Ramirez-Mendoza H, Mercado C, Espinosa S, Vallejo $\mathrm{V}$, Reys-Leyva J, et al. Semen alterations in porcine rubulavirusinfected boars are related to viral excretion and have implications for artificial insemination. Res Vet Sci 2007;83:403-9.

[42] Wrathall A, Mengeling W. Effect of inseminating seropositive gilts with semen containing porcine parvovirus. $\mathrm{Br}$ Vet $\mathrm{J}$ 1979;135:420-5.

[43] Mateusen B, Van Soom A, Maes D, Favoreel H, Nauwynck H. Receptor-determined susceptibility of preimplantation embryos to pseudorabies virus and porcine reproductive and respiratory syndrome virus. Biol Reprod 2007;76:415-23.

[44] Yaeger M, Prieve T, Collins J, Christopher-Hennings J, Nelson E, Benfield D. Evidence for the transmission of porcine reproductive and respiratory (PRRS) syndrome virus in boar semen. Swine Health Prod 1993;1:7-9.
[45] Prieto C, Suárez P, Simarro I, García C, Martín-Rillo S, Castro J. Insemination of susceptible and preimmunized gilts with boar semen containing porcine reproductive and respiratory syndrome virus. Theriogenology 1997;47:647-54.

[46] Swenson S, Hill H, Zimmerman J, Evans L, Wills R, Yoon K, et al. Artificial insemination of gilts with porcine reproductive and respiratory syndrome (PRRS) virus-contaminated semen. Swine Health Prod 1994;2:19-23.

[47] Benfield D, Nelson C, Steffen M, Rowland R. Transmission of PRRSV by artificial insemination using extended semen seeded with different concentrations of PRRSV.. In: Proceedings of the 31st annual meeting of the American association of swine practitioners; 2000. p. 405-8.

[48] Prieto C, Suárez P, Bautista J, Sánchez R, Rillo S, Simarro I, et al. Semen changes in boars after experimental infection with porcine reproductive and respiratory syndrome (PRRS) virus. Theriogenology 1996;45:383-95.

[49] Prieto C, Castro J. Porcine reproductive and respiratory syndrome virus infection in the boar: a review. Theriogenology 2005;63:1-16.

[50] Darcel C, Coulter G. IBR virus neutralizing substance in bull seminal fluid and its removal prior to attempts at viral isolation from semen. Can Vet J 1976;17:318-20.

[51] van Rijn P, Wellenberg G, Hakze-van der Honing R, Jacobs L, Moonen P, Feitsma H. Detection of economically important viruses in boar semen by quantitative Real Time PCR technology. J Virol Methods 2004;120:151-60.

[52] Christopher-Hennings J, Nelson E, Nelson J, Hines R, Swenson S, Hill H, et al. Detection of porcine reproductive and respiratory syndrome virus in boar semen by PCR. J Clin Microbiol 1995;33:1730-4.

[53] Swenson S, Hill H, Zimmerman J, Evans L, Wills R, Yoon K, et al. Preliminary assessment of an inactivated PRRS virus vaccine on the excretion of virus in semen. Swine Health Prod 1995;3:244-7.

[54] Nielsen T, Nielsen J, Have P, Baekbo P, Hoff-Jørgensen R, Bøtner A. Examination of virus shedding in semen from vaccinated and from previously infected boars after experimental challenge with porcine reproductive and respiratory syndrome virus. Vet Micriobiol 1997;54:101-12.

[55] Amass S, Baysinger A. Diseases of swine. In: Straw B, Zimmerman J, D'Allaire S, Taylor D, editors. Swine disease transmission and prevention. 9th ed., Ames, IA, USA: Blackwell Publishing; 2006. p. 1075-98.

[56] Kim J, Han D, Choi C, Chae C. Differentiation of porcine circovirus (PCV)-1 and PCV-2 in boar semen using a multiplex nested polymerase chain reaction. J Virol Methods 2001;98: 25-31.

[57] Christopher-Hennings J, Nelson E, Nelson J, Rossow K, Shivers J, Yaeger M, et al. Identification of porcine reproductive and respiratory syndrome virus in semen and tissues from vasectomized and nonvasectomized boars. Vet Pathol 1998; $35: 260-7$.

[58] Swenson S, Hill H, Zimmerman J, Evans L, Landgraf J, Wills R, et al. Excretion of porcine reproductive and respiratory syndrome (PRRS) virus in semen after experimentally induced infection in boars. J Am Med Assoc 1994;204:1943-8.

[59] Reicks DL, Munoz-Zanzi C, Mengeling W, Christopher-Hennings J, Lager K, Polson D, et al. Detection of porcine reproductive and respiratory syndrome virus in semen and serum of boars during the first six days after inoculation. J Swine Health Prod 2006;14:35-41. 